\title{
Multi-Component Vaccines for Suppression of Type 1 Diabetes
}

\author{
William H.R. Langridge and Oludare J. Odumosu \\ Loma Linda University School of Medicine, \\ Center for Health Disparities and Molecular Medicine, Loma Linda, \\ U.S.A.
}

\section{Introduction}

Many individual therapeutic strategies involving oral delivery of diabetes autoantigens such as insulin and GAD have been shown to provide partial short term suppression of organ specific type 1 diabetes autoimmunity (Weiner et al. 1991; Zhang et al. 1991; Nakayama et al. 2005). However, few individual therapies have been able to demonstrate effective, safe and persistent protection against type 1 diabetes onset or progression (Hutchings and Cooke 1998). More recently, combinatorial therapeutic strategies that incorporate immunostimulatory molecules such as the cholera toxin B subunit (CTB), linked to a diabetes autoantigen (eg. insulin or GAD), were shown to substantially enhance immune suppression of juvenile (Type 1) diabetes autoimmunity to provide more effective, safe and sustainable disease prevention (Arakawa et al. 1998; Denes et al. 2006). Combinatorial vaccines involving oral delivery of the cholera toxin B subunit (CTB) linked to pancreatic autoantigens such as proinsulin and GAD delivered together were shown to provide additive enhancement of autoantigen mediated suppression of diabetes insulitis and hyperglycemia in contrast to inoculation of prediabetic mice with CTB::GAD or CTB::proinsulin alone (Arakawa, Chong, and Langridge 1998). Most recently, combinatorial DNA vaccination experiments including genes encoding CTB::GAD together with the immunosuppressive cytokine IL-10 were shown to completely suppress type 1 diabetes onset in non-obese prediabetic (NOD) mice (Denes et al. 2010). Thus, it is now clear that combinatorial vaccination strategies have the ability to completely prevent diabetes onset in genetically susceptible mammals.

However, to harness and transfer this promising combinatorial vaccination strategy for effective and safe clinical therapy in type 1 diabetes patients, cellular and molecular mechanisms underlying multi-component vaccine stimulation of immunological tolerance must be defined. Initial steps required to attain this goal, will involve identification of mechanisms responsible for vaccine interactions with cells of the innate immune system i.e., dendritic cells (DCs), involved in the initial processing vaccine autoantigens.

In order to understand how multi-component vaccines may function to prevent the development of chronic islet inflammation (insulitis) progressing to high blood sugar (hyperglycemia), it will be important to understand the nature of immune responses underlying type 1 diabetes disease onset. To accomplish this goal, hypotheses must be tested that suggest how adjuvant-autoantigen fusion proteins may enhance immunotolerance e.g. 
through initial activation of sensor cells of the innate immune system predominantly immature dendritic cells (iDC). Of importance will be to determine how DCs process adjuvant-autoantigen fusion proteins, and how these processing reactions result in the initiation of immuno-reactive or immuno-suppressive $\mathrm{T}$ cell populations responsible for inhibiting the development of autoreactive effector $\mathrm{T}$ cell responses? Throughout the development of this review, we will examine the role of protein adjuvants such as CTB in combination with autoantgens and anti-inflammatory cytokines that can act in concert to stimulate proliferation and activation of regulatory $\mathrm{T}$ cell subsets potentially key players in the inhibition of DC maturation and stimulation of $\mathrm{T}$ cell morphogenesis into autoreactive $\mathrm{T}$ cells. To rescue the large numbers of existing diabetes patients in which diabetes has progressed to a hyperglycemic state, it will be important to understand mechanisms responsible for diabetes development and how combinatorial vaccines may interact with cells of the immune system to suppress diabetes progression. An improved understanding of these mechanisms will establish a basis for development of safer, more effective and durable vaccine strategies for prevention of diabetes onset and for improvement of combinatorial therapeutic strategies for restoration of immunological homeostasis and ultimately restoration of euglycemia in type 1 diabetes patients.

\section{Type 1 diabetes results from genetic predisposition and a breakdown in the mechanisms responsible for immunological tolerance}

In juvenile diabetes mellitus, (type 1 diabetes), insulin-producing beta cells in the pancreatic Islets of Langerhans are attacked and destroyed by aberrant immune responses to insulin and progressively to other islet beta cell products. Diabetic patients that have progressed to hyperglycemia must regularly inject insulin multiple times a day, or risk diabetic shock, coma and death. Regulation of immunological homeostasis, among the approximate $10^{14}$ commensal microorganisms living on the $10^{13}$ cells of the human body's mucosae requires a delicate balance of activation and suppression of immunity, (Lodinova-Zadnikova et al. 2004). The first step in disruption of homeostasis leading to islet-cell mortality is initiated by events that trigger maturation of antigen-presenting cells (APCs), largely dendritic cells (DC), responsible for inducing the morphogenesis of autoreactive CD8+, CD4+ T cells and B cells, which results in the production of anti-beta cell antibodies (Atkinson et al. 1994; Han et al. 2005; Tisch and McDevitt 1996). The continuous loss of islet $\beta$-cell function results in a progressive deficiency of insulin production leading to a gradual elevation of blood sugar levels (hyperglycemia), that triggers an increase in cellular oxidative stress leading to chronic inflammation and an associated risk for secondary neural and circulatory pathological complications that include amputation, blindness, kidney failure, heart attack and stroke (Libby et al. 2005; Shen and Bornfeldt 2007). Diabetes hyperglycemia represents the end stage of an immunological process that develops over months in mice to years in humans (Vendrame, Zappaterreno, and Dotta 2004). While most type 1 diabetes (T1D) cases develop in pre-adolescence, late onset diabetes (LADA), may appear generally from 40-60 $\mathrm{yr}$ of age and is often confused with type 2 diabetes. The progression of diabetes symptoms may be responsible for $10-15 \%$ of diabetes related heart disease mortality especially in low income socio-economic groups which are at greatest risk for diabetes related health disparities in the U.S (Kobayashi et al. 2006; Maioli, Puddu, and Pes 2006). Diagnosis and treatment of hyperglycemia is poor, as islet $\beta$-cell destruction is completely asymptomatic until more than half of the approximately $1 \times 10^{6}$ pancreatic islets have been destroyed or 
inactivated (Tang et al. 2006). Approximately 3 million Americans, or about $15-20 \%$ of citizens currently afflicted with all forms of diabetes, suffer from type 1 diabetes and > 13,000 children are diagnosed with type 1 diabetes in the U.S. annually - (about 35 children / day), (International 2005). Alarmingly, type 1 diabetes in pre-adolescent children is increasing at about 0.3-0.5\% annually, (Gale 2002; International 2005). Familial inheritance studies show that genetic predisposition factors (genotype DRB1*0301/04, DQB1*0201/0302), play a significant role in T1D development (Rewers et al. 1996). At least 15 genetic loci have been linked to T1D in the non-obese diabetic (NOD) mouse, a relevant mammalian T1D model (Makino et al. 1980). In humans, genetic risk factors were identified in the leukocyte antigen (HLA) complex on chromosome 6, CTLA-4 gene polymorphisms on chromosome 2, and in the insulin gene variable number tandem repeat region on chromosome 11 (Onengut-Gumuscu and Concannon 2002). Since Type 1 diabetes ranges from $23-53 \%$ among monozygotic twins, genetic risk factors are insufficient to account for disease occurrence (Tatersall R. B. 1972).

Environmental factors, including virus infection and dietary components are considered to modify diabetes susceptibility (Jun and Yoon 2001; Akerblom HK 2002). Cytotoxic CD8+ T cells were shown to be involved in diabetes initiation and progression(Walter and Santamaria 2005). Further, recruitment of naïve diabetogenic $\beta$-cell-reactive CTLs to the pancreatic islets were shown to require $\beta$-cell-reactive CD4+ Th1 cells(Delovitch and Singh 1997). Following CD4 ${ }^{+}$Th cell infiltration of pancreatic islets in NOD mice, autoreactive Th1 lymphocytes were shown to secrete inflammatory cytokines IFN- $\gamma$ and IL-2 that stimulate macrophage and CTL secretion of oxidative compounds and inflammatory cytokines that induce chronic pancreatic inflammation (insulitis), ultimately responsible for apoptosis of islet insulin-producing $\beta$-cells(Romagnani 1998). Diabetes onset is not always marked by circulating auto-Ab to $\beta$-cell autoantigens and a variety of immune cells including $\mathrm{B}$ cells, dendritic cells, macrophages and natural killer (NK) cells have been shown to be involved in diabetes pathogenesis(Yoon, Jun, and Santamaria 1998; Dai, Carayanniotis, and Sercarz 2005; Tian et al. 2006; Silveira and Grey 2006; Cardell 2006). A recently identified rat diabetes model was shown to be quantitatively up-regulated from $2.0-100 \%$ diabetes by antibody depletion of regulatory $\mathrm{T}$ cells suggesting a significant role for regulatory $\mathrm{T}$ cells in diabetes suppression(Mordes et al. 2005). Thus, dendritic cell, autoreactive $\mathrm{T}$ cell, $\mathrm{T}$ regulatory cell and $B$ cell pathways may all interact to establish or break immunological homeostasis(Mostarica-Stojkovic 2005).

\subsection{Diabetes autoantigen therapy can restore immunological tolerance}

While, deletion of autoreactive $\mathrm{T}$ cells is generally achieved in the thymus (central tolerance), a few autoreactive $\mathrm{T}$ lymphocytes escape deletion and appear in the periphery(Song et al. 2004). Interestingly, autoreactive $\mathrm{T}$ cell clones specific for self-proteins were shown to arise spontaneously from normal peripheral blood mononuclear cells in healthy people (Wucherpfennig et al. 1994). Thus, autoimmunity may have the opportunity to exist to some degree in everyone. Insulin was shown to be an early major diabetes autoantigen(Palmer et al. 1983; Jaeckel, Lipes, and von Boehmer 2004; Jaeckel et al. 2003; Kent et al. 2005). The insulin leader, A, B and C protein chains all were shown to contain CD4+ and CD8+ immunodominant T cell epitopes (Di Lorenzo, Peakman, and Roep 2007). Progressive islet $\beta$-cell destruction was shown to lead to the appearance of additional $\beta$-cell autoantigens (Ag spreading), a factor that exacerbates $\beta$-cell destruction(Baekkeskov et al. 
1990). Immunotherapy with major $\beta$-cell antigens such as insulin, glutamate decarboxylase (GAD), or heat shock protein (hsp60), was shown to delay or even prevent the onset of type 1 diabetes, providing a potentially useful therapeutic approach to treatment of $\mathrm{T}$ cellmediated autoimmunity(Elliott et al. 1994; Tisch and McDevitt 1996). Oral inoculation with small amounts of islet autoantigens was shown to induce self-tolerance through IL-4 and Stat 6 activation of $\mathrm{CD} 4^{+}$Th2 and Th3 regulatory T cells that down-modulate autoreactive effector T cell inflammation at close proximity e.g., "bystander suppression", (Hommann et al. 2001; Weiner 2001). Protection against T1D was shown to be associated with Th3 regulatory lymphocyte secretion of TGF- $\beta$ in prediabetic NOD mice gavaged with insulin, (Zhang et al. 1991). Further, oral auto-Ag inoculation generated partial diabetes suppression in patients (Millington, Mowat, and Garside 2004; Chaillous et al. 2000). In several related Th1 cell mediated autoimmune diseases, collagen-induced arthritis (Thompson and Staines 1986) and encephalomyelitis (Higgins and Weiner 1988) disease suppression was observed after prolonged feeding of small amounts of specific auto-Ags. The induction of multiple sclerosis in animals was not only halted but reversed by feeding small amounts of myelin basic protein suggesting that this type of oral auto-Ag therapy can suppress and even aid in recovery from autoimmunity (Bitar and Whitacre 1988).

\subsection{Cholera toxin B subunit (CTB), enhances autoantigen mediated immunotolerance}

Immunotherapy with adjuvants such as Complete Freund's Adjuvant (CFA) co-injected intradermally with insulin, or inoculation with CTB-insulin B chain polypeptide fusion proteins significantly suppressed diabetes early onset demonstrating the usefulness of immunostimulatory molecules in diabetes suppression (Hutchings and Cooke 1998). Additional studies in BB rats suggest that CFA may mediate diabetes suppression through induction of regulatory T cells (Qin et al. 1993). Thus, a number of biological mechanisms may contribute to suppression of autoimmunity. Cholera toxin (CTX), from Vibrio cholerae contains a toxic ADP-ribosyltransferase A subunit (CTA1), linked by a small helical (A2) peptide to a pentamer of non-toxic carrier B subunits (CTB), (Eriksson and Holmgren 2002). CTX induces DC maturation and migration to the Peyer's patches while the CTB subunit was shown to inhibit DC maturation and to bind GM1-ganglioside, a receptor found on most epidermal cells, thereby providing an efficient transmucosal carrier for autoantigen induction of peripheral tolerance (Shreedhar, Kelsall, and Neutra 2003; Lycke 2004; Sun, Holmgren, and Czerkinsky 1994). Oral delivery of CTB was shown to directly stimulate DC induction of T cell IL-4 secretion and to exert a variety of distinct anti-inflammatory effects resulting in immunological suppression (Holmgren et al. 1994; Li and Fox 1996; Holmgren and Czerkinsky 2005). Oral delivery of CTB conjugated to specific autoantigens was shown to protect mice against several Th1 cell mediated autoimmune diseases including autoimmune encephalomyelitis (Sun et al. 1996; Sun et al. 2000), autoimmune chondritis (Kim et al. 2001) and uveitis (Phipps et al. 2003). Further, CTB-insulin conjugates were shown to suppress diabetes in NOD mice (Bergerot et al. 1997; Arakawa, Chong, and Langridge 1998), a result associated with reduced IFN- $\gamma$ production and Tr1 regulatory $\mathrm{T}$ cell migration into pancreatic islets (Aspord et al. 2002; Roncarolo et al. 2001). Further, linkage of CTB to insulin generated up to a 10,000-fold reduction in autoantigen required for immuno-tolerization (Bergerot et al. 1997; Arakawa et al. 1998; George-Chandy et al. 2001). Thus, current evidence suggests that mechanisms responsible for CTB modulated immune suppression may include inhibition of DC maturation by suppressing the expression of 
surface co-stimulatory molecules resulting in the increased secretion of IL-10 and a concurrent suppression of IL-12, inhibition of autoreactive $\mathrm{T}$ cell development and/or stimulation of Th2 and regulatory T cell proliferation and activation (Marinaro et al. 1995; Lavelle et al. 2003; Odumosu et al. 2010).

\subsection{Dendritic cells can initiate immunological tolerance}

Dendritic cells may play a primary role in antigen priming of naïve T helper cells (Th0) and modulation of their development into autoreactive Th1 or immunosuppressive Th2 lymphocytes important for maintenance of immunological homeostasis (Pulendran et al. 1999; Pulendran et al. 2001; Itano et al. 2003).

Immuno-cytochemical analyses showed that oral inoculation of autoantigens results in their uptake from $\mathrm{M}$ cells in the intestinal mucosa into peripheral (lamina propria) DCs via several routes that may influence the nature of the immune response (Yoon and Jun 2005).

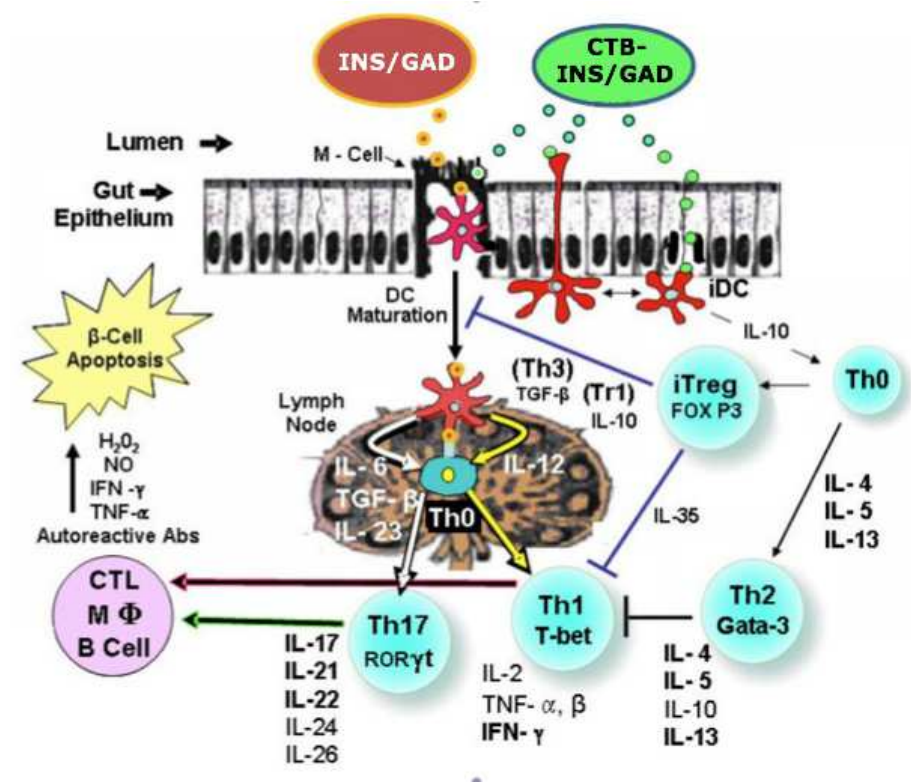

Fig. 1. Adjuvant-autoantigen fusion protein suppression of autoimmunity. Immature dendritic cells (iDC) take up CTB:GAD/Insulin autoantigen fusion proteins through the intestinal epithelium. Low levels of oral delivered auto-Ags stimulate DC secretion of antiinflammatory cytokines IL-10 and IL-4 which guide cognate naïve Th0 lymphocyte development of into immunosuppressive Th2 and iTreg lymphocyte phenotypes (Iwasaki and Kelsall 2000; Afzali et al. 2007).

Autoantigens may be taken up and processed by immature, partially activated semi-mature or mature DC subsets (Lutz and Schuler 2002). These DCs may remain in the periphery or migrate to lymph nodes, where they present antigen peptides on MHCII receptors, synthesize co-stimulatory molecules and in the absence of additional cytokine production, may induce the morphogenesis of Ag-specific IL-10 producing CD4+CD25+ T regulatory (Tr1) cells (Enk 2005) Figure 1. Co-stimulation appears to be less or absent for tolerogenic 
responses, thus, interactions between autoantigens, DCs and T cells in the gut associated lymphoid tissues may result in tolerogenic outcomes following autoAg presentation (Lycke 2004). Peyer's patches DCs that synthesize IL-10 were shown to down-regulate Th1 cell mediated autoimmunity (Steinbrink et al. 1997). Immature or peripheral DCs (iDCs), that had low expression of co-stimulatory molecules, secreted cytokine IL-10, remained in the periphery and were shown to induce Th2 lymphocyte mediated immunological tolerance (Rissoan et al. 1999; Liu et al. 2001; Li et al. 2006). Further studies showed that a major function of peripheral iDCs was maintenance of self-tolerance (Wilson, El-Sukkari, and Villadangos 2004; Steinman and Pope 2002). In alternative, experiments, adding IL-12 to iDCs induced Th1 cell morphogenesis and accelerated type 1 diabetes in NOD mice (Trembleau et al. 1995). In response to microbial antigens, DCs may secrete inflammatory cytokines IL-6 and IL-23 that stimulate naïve Th0 cell development into IL-17 inflammatory cytokine secreting Th17 effector T cells (Figure 1). Th17 cells have been implicated in the induction of organ-specific autoimmune arthritis, multiple sclerosis, psoriasis, and inflammatory bowel disease as well as type 1 diabetes (Cua et al. 2003; Langrish et al. 2005; Duerr et al. 2006; Murphy et al. 2003; Nakae et al. 2003; Zheng et al. 2007; Mensah-Brown, Shahin, Al-Shamisi et al. 2006; Mensah-Brown, Shahin, Al-Shamsi et al. 2006). Together, the experimental evidence suggests development of type 1 diabetes may be under DC control (Shinomiya et al. 1999). However, there is some debate about the role of Th17 cells in diabetogenesis suggesting that Th17 cells are not important in the disease process but rather are plastic cell that become become Th1(Bending et al. 2009).

\subsection{CTB enhances immune tolerance by upregulating DC tolerogenic toll-like receptors}

Dendritic cells, macrophages, and granulocytes derived from hematopoietic stem cells provide the first line of defense against infectious pathogens attacking mucosal surfaces. Thus, DCs (found in most abundance in the mucosae and skin), must recognize pathogen antigens, autoantigens and innocuous antigens in order to maintain immunological homeostasis. To accomplish this task, DCs bind small conserved pathogen antigen segments; pathogen associated molecular patterns (PAMPS), to their trans-membrane tolllike receptor (TLR) domains, (Takeda, Kaisho, and Akira 2003; Wen et al. 2004). Different PAMPS stimulate specific TLRs that activate one of several DC signal transduction pathways leading to synthesis of transcriptional regulators e.g., NFkB. These transcriptional activators switch on genes encoding specific cytokines, costimulatory molecules and chemokines that enable DCs to direct naïve cognate Th0 cell development into (1) immunoreactive Th1 lymphocytes, (2) immunosuppressive Th2 effector cell and (3) T regulatory cell subsets (Kaisho and Akira 2002). Autoreactive T cells involved in experimental autoimmune encephalomyelitis (EAE) and other chronic inflammatory autoimmune diseases are considered to follow TLR defined pathways of DC processing and auto-Ag presentation triggered by environment signals (Haverkos et al. 2003; Bach 2005). Recently, examination of TLR2 and TLR4 expression in monocytes from T1D patients showed that TLR2 and TLR4 surface expression and mRNAs were significantly increased in T1D monocytes in comparison with the controls (Devaraj et al. 2007). Further, downstream targets of TLRs, NFKb, MyD88, Trif and pIRAK, were also significantly upregulated. Antigen ligation to TLR2 is generally known to induce a Th2 immunosuppressive cytokine profile (Ferwerda et al. 2005). Whether CTB binds and activates TLR2 or TLR4 is presently 

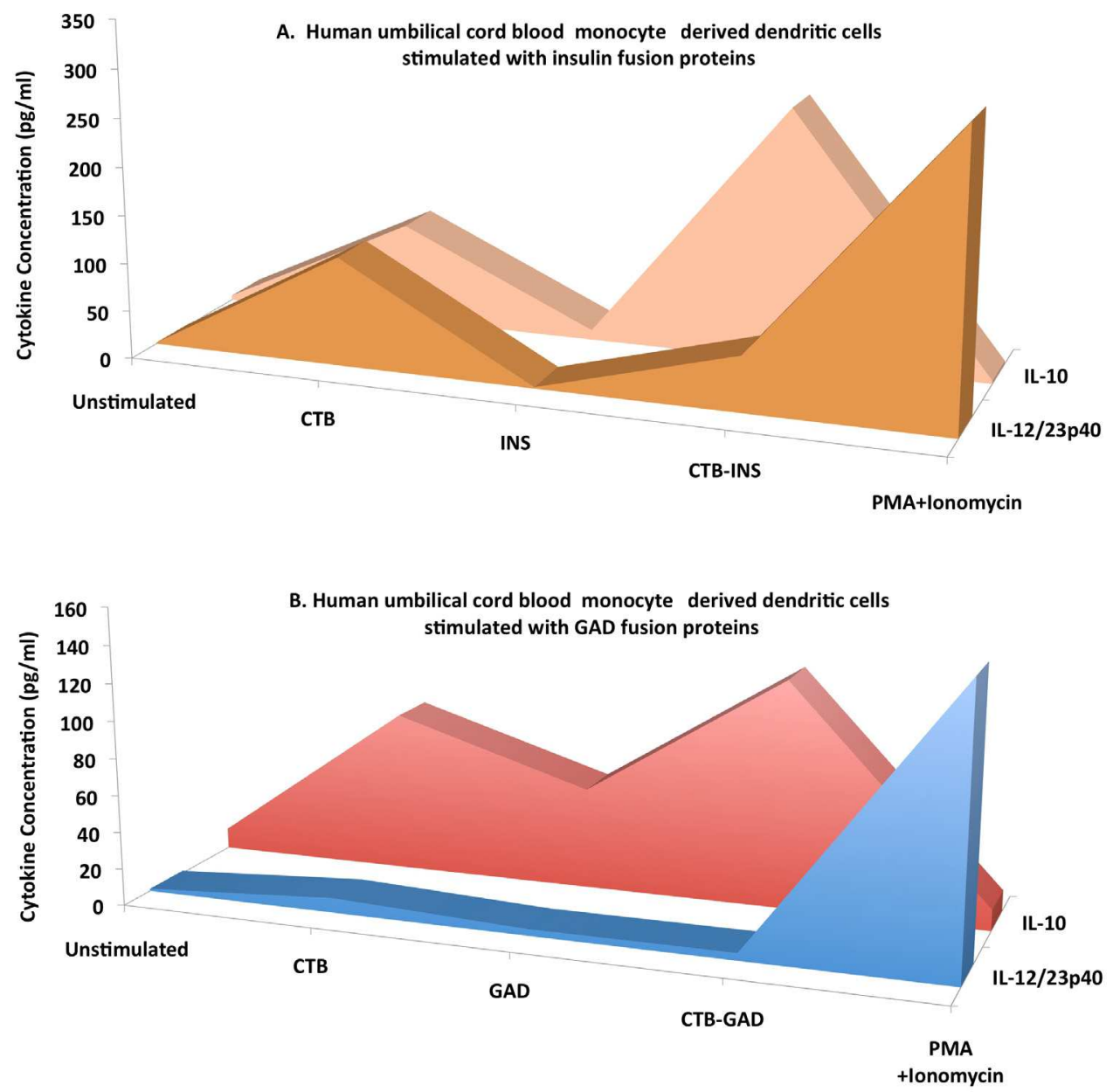

Fig. 2. Measurement of anti-inflammatory cytokine IL-10 and inflammatory cytokine IL12/23p40 subunit levels by Cytometric Bead Array flow cytometry, from cell supernatants removed from iDCs inoculated with CTB-insulin (CTB::INS) fusion protein, (Panel A) or CTB::GAD fusion protein (Panel B). For each treatment the concentration of IL-10 and IL$12 / 23$ p40 subunit was normalized to standard IL-10 and IL-12/23p40 cytokine curve and given in $\mathrm{pg} / \mathrm{ml}$. The data represent the Mean and SE $\left({ }^{*} \mathrm{P}<0.001\right)$ of repeated independent experiments in comparison with the control sample.

unknown. However, the structurally similar E. coli AB enterotoxin B subunit (LTB) was shown to stimulate TLR2, resulting in regulatory $\mathrm{T}$ cell proliferation which ultimately lead to inhibition of iDC maturation, IL-10 secretion and induction of immunosuppressive Th2 lymphocyte development (Hajishengallis et al. 2005; Sutmuller et al. 2006). Examination of CTB mediated suppression of DC maturation suggests that TLR2 may be selectively upregulated (Odumosu et al. 2010). The observed selectivity may be due to TLR2 dependent 
hydrophobic interactions for ligand binding as previously observed for the E. coli enterotoxin B subunit LTBIIb (Seong and Matzinger 2004; Okusawa et al. 2004). Alternatively, multiple bacterial products including lipo-polysaccharide (LPS), were shown to undergo DC processing independently of TLR signaling, via stimulation of the pannexin 1 hemi-channel protein-cryopyrin receptor pathway (Kanneganti et al. 2007) Thus, in addition to immunosuppressive TLR receptor binding, alternative signaling pathways could be involved in iDC processing of CTB-INS fusion protein potentially favoring CTB induced DC synthesis of IL-10 leading to induction of Th0 $\rightarrow$ Th2 cell morphogenesis and suppression of autoreactive Th1 lymphocyte development ( Figure 2).

\subsection{Regulatory T cells inhibit dendritic cell maturation}

The suppression of autoreactive $\mathrm{T}$ cells is essential for establishment of peripheral tolerance and maintenance of immunological homeostasis, (Vigouroux et al. 2004; Stassen et al. 2004). Natural CD4+CD25+ regulatory T cells (nTregs) of thymus origin, have a high avidity for self-antigens and were shown to link central tolerance to induction of regulatory functions in the periphery (Sakaguchi et al. 1995; Sakaguchi and Sakaguchi 2005; Sakaguchi 2005; Taams and Akbar 2005; Bresson et al. 2006). Natural Treg immunosuppressive functions are antigen independent and are largely under control of the forkhead box p3 transcription factor FOXP3 (Fontenot, Gavin and Rudensky 2003; Hori, Nomura and Sakaguchi 2003). While nTregs inhibit DC maturation in an antigen independent manner, they were also shown to be important for down-regulating Th1 cell mediated autoimmunity in thyroiditis, diabetes, encephalomyelitis, and oophoritis (Tarbell et al. 2004). Further, the glucocorticoid-induced tumor necrosis factor receptor (GITR), cytotoxic T-lymphocyte antigen 4 (CTLA-4), and LAG-3 surface markers were identified on antigen-activated nTregs (Nocentini and Riccardi 2005; Huang et al. 2004; Oderup et al. 2006). Further evidence supporting Treg suppression of autoimmunity, mutations in the mouse foxp3 gene resulted in development of systemic autoimmunity, characterized by inflammatory lymphocyte infiltration and destruction of tissues by autoreactive T-cells, leading to spontaneous development of a number of Th1 cell mediated autoimmune diseases including type 1 diabetes (Hori and Sakaguchi 2004; Ehrenstein et al. 2004; Lindley et al. 2005; Viglietta et al. 2004).

Incubation of DCs with nTregs increased IL-10 secretion and reduced CD40, CD80/86 costimulatory molecule expression reinforcing the hypothesis that nTregs modulate autoimmunity through suppression of DC immunostimulatory functions (Veldhoen et al. 2006; Misra et al. 2004; Yang et al. 2006). Recent experiments clearly show that Tregs interact with antigen-bearing DCs to prevent naïve autoreactive CD4+CD25-- effector Th0 cell priming (Tang et al. 2006). Adoptive transfer experiments further confirmed nTreg-DC interaction was essential for autoreactive Th1 cell inhibition (Tarbell et al. 2004; Kelsen et al. 2006). Regulation of DC processing of autoantigens, in the absence of sufficient nTregs, requires additional regulatory $\mathrm{T}$ cell induction from the CD4+ CD25-- $T$ cell population(Bluestone and Abbas 2003; Filippi, Bresson, and von Herrath 2005) . Two human CD4+CD25+ nTreg subsets were shown to convey immuno-suppressive capabilities to CD4+ CD25-- T cells. Natural Tregs expressing $\alpha 4 \beta 7$ integrin induced IL-10 secreting Tr1like suppressor T cells, while nTregs expressing $\alpha 4 \beta 1$ integrin induced TGF- $\beta$ secreting Th3like suppressor T cells (Stassen et al. 2004). Secreted TGF- $\beta 1$ was shown to suppress DC activation during maturation (Rastellini et al. 1995; Yamaguchi et al. 1997; King et al. 1998). 
Further, TGF- $\beta 1$ inhibited DC expression of chemokine receptor CCR7, responsible for DC migration to lymph nodes (MartIn-Fontecha et al. 2003). Secretion of IL-10 by Tr1 iTregs inhibited DC maturation by blocking IL-12 synthesis and skewing Th1/Th2 polarity toward Th2 cells in vivo by inhibiting both Th1 cell proliferation and monocyte secretion of IFN- $\gamma$, TNF- $\beta$ and IL-2 cytokines (De Smedt et al. 1997; Sela 2006). DCs were shown to expand and differentiate Foxp3+CD25+CD4+ Tregs from Foxp3-CD25-CD4+ thymocytes with specificity for self-antigens presented by thymic medullary DCs maturing in response to thymic stromal lymphopoietin (Watanabe et al. 2005). In vivo, repeated injection of preprocessed peptides (Apostolou and von Boehmer 2004) or the targeting of intact antigens to immature DCs (Kretschmer et al. 2005) convert antigen-specific Foxp3-CD25-CD4+ T cells to Foxp3+CD25+CD4+ Tregs bearing the same TCR. DCs also induce other regulatory populations, such as IL-10-producing Tr1 (Levings et al. 2005; Akbari, DeKruyff, and Umetsu 2001; Akbari et al. 2002; Stock et al. 2004) and IL-10-producing regulatory DCs (Kojo et al. 2005). Diabetes-susceptible NOD mice appear to generate normal numbers of Foxp3 Tcells over their lifetimes (Tritt et al. 2008). However, Piccirillo and his colleagues at McGill University showed that T-cell functional potency declined with age, leaving potential autoimmune responses in the pancreas unchecked. These authors suggest that certain genetic predispositions, coupled with the possible contribution of external environmental factors or infections, could potentially alter regulatory T-cell function in susceptible individuals and trigger a full-scale diabetic autoimmune reaction in the pancreas (Tritt et al. 2008).

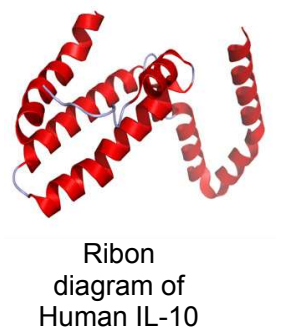

\subsection{Immunosuppressive properties of anti-inflammatory cytokine IL-10}

Human IL-10 is a homodimeric anti-inflammatory cytokine protein (molecular structure at left), with a subunit length of 160 amino acids and 73 percent amino acid homology with its murine orthologue(Yoon et al. 2006; Moore et al. 1990). Mouse knockout studies showed that IL-10 down-regulates autoimmunity in the intestinal tract and is active in suppression of Crohn's disease (Minderhoud, Samsom, and Oldenburg 2007, 2007). In confirmation, the inability to clear persistent viral infections was shown to result from T-cell inactivation generated by APC up-regulation of anti-inflammatory IL-10 biosynthesis (Seyfert-Margolis et al. 2006). Thus, suppression of inflammatory responses mediated by DC up-regulation of IL-10 may play a significant role in virus-mediated suppression of type 1 diabetes in NOD mice and BB rats (Tracy and Drescher 2007; Schwimmbeck, Dyrberg, and Oldstone 1988). Alternative mechanisms that may play a role in cytokine enhancement of immune suppression include IL-10 blockage of NF-kappa B activity and regulation of the JAK-STAT signaling pathway (Donnelly, Dickensheets, and Finbloom 1999; Leceta et al. 2000).

A regulatory role for autocrine IL-10 has been described for APCs such as monocytes, macrophages and dendritic cells (de Waal Malefyt et al. 1991; Sica et al. 2000). Autocrine 
production of IL-10 by immature DCs, was shown to inhibit production and release of proinflammatory cytokines (IL-12, TNF-a, IL-6, LTB4, NO, PGE2), and to suppress Th1 lymphocyte activity by down-regulation of costimulatory molecule expression on the APC surface (Harizi and Gualde 2006; Grutz 2005; Moore et al. 1993). Through inhibition of these endogenous pro-inflammatory mediators, IL-10 has demonstrated a central role in downregulating DC mediated inflammatory responses and maintenance of DCs in an immature state (Harizi and Gualde 2006).

In paracrine fashion, IL-10 synthesized by DCs can regulate immune responses by altering the function of different adjacent cell types. In several studies IL-10 secreted by iDCs stimulated morphogenesis of cognate Th0 cell development into immunosuppressive Th2 lymphocytes, or into suppressor CD4+ regulatory T cells (Stassen, Schmitt, and Jonuleit 2004; Romagnani et al. 1998). In addition, IL-10 was shown to increase effector functions of CD8+ T cells (Groux et al. 1999). In addition, IL-10 may be crucial for controlling chronic inflammatory responses in vivo. Inhibition of LPS-induced CD40 signaling by IL-10 suppressed multiple sclerosis and rheumatoid arthritis, confirming the value of IL-10 as a therapeutic for autoimmunity (Qin et al. 2006). Further, IL-10 was shown to play a role in partial suppression of type 1 diabetes (Slavin, Maron, and Weiner 2001; Battaglia et al. 2006; Goudy et al. 2001; Goudy et al. 2003). Thus, through activation of several biological mechanisms, IL-10 may provide significant enhancement to CTB-diabetes autoantigen mediated immune suppression.

\subsection{Virus vaccine delivery does not inhibit immunotolerance}

In addition to its function as a vehicle for subunit vaccine delivery, vaccinia virus was shown to stimulate production of anti-inflammatory cytokines IL-10 and TGF- $\beta$ in skin epithelial cells(Liu et al. 2005). As these cytokines are known to inhibit inflammation and Th1 responses, vaccinia demonstrates properties known to suppress inflammation. Further, vaccinia virus expressing the pancreatic islet auto-Ag glutamic acid decarboxylase (GAD) was shown to be $90 \%$ effective in prevention of diabetes in NOD mice (Jun, Khil, and Yoon 2002; Jun et al. 2002). (1) Vaccinia multiplies in the cytoplasm, excluding genetic modification of infected cells (Moss 1996). (2) All human cell types tested produce viral infection with high efficiency. Viral or foreign proteins are synthesized and undergo appropriate post-translational modification (Moss 1991). (3) Multiple autoantigen genes (up to $25 \mathrm{~kb}$ ), can be tolerated in dispensable regions of the vaccinia genome without impacting virus growth. (4) Because recombinant vaccinia virus proteins expressed in mammalian cells are properly folded, processed and transported normally, they can be used to induce or bind antibodies that recognize conformational epitopes (Otteken, Earl, and Moss 1996). (5) The safety of a live attenuated VV vaccine was clearly shown in a major smallpox eradication program (Moss 1991). (6) Patients injected with an attenuated VV strain expressing cytokines showed no evidence of systemic virus spread, organ dysfunction or other major hematological or biochemical changes (Robinson, Cornelius et al. 1998; Robinson, Mukherjee et al. 1998; Mastrangelo et al. 1999). (7) Construction of safer, hyper-attenuated replicationdeficient and -competent strains of vaccinia is underway (Denes et al. 2006), which could be used for treatment of diabetes. Recent experiments in our laboratory showed that vaccinia virus delivered CTB-INS autoantigens suppress type 1 diabetes insulitis and hyperglycemia in NOD mice (Denes, Fodor and Langridge 2010). Of specific relevance to this proposal, addition of vaccinia as an alternate CTB-INS delivery vehicle will permit priming and boosting CTB-INS immunosuppressive responses without the possibility for generation of 
immunity to the vector, which could potentially ameliorate immunological tolerization to the autoantigen and degrade the contribution of the adjuvant to enhanced immunosuppression. Further, delivery of subunit vaccines, which are often lacking in immunogenicity may benefit from increased immunostimulation provided by heterologous prime/boost inoculation regimes. Vaccinia prime, plant boost strategies may provide an increased level of immunosuppression.

\subsection{Plants block type 1 diabetes onset and act as production and delivery vehicles for diabetes vaccines.}

The $\mathrm{B}$ subunit of the $\mathrm{AB}$ toxin isolated from the castor oil plant Ricinus communis, when linked as a fusion protein at the C-terminus of proinsulin and expressed in potato plants, was shown to significantly suppress the onset of type 1 diabetes (Carter et al. 2010; Carter et. al. 2006). Because food plants are generally devoid of pathogen associated molecular patterns (PAMPs), they are well tolerated by the inate and adaptive arms of the immune system. Their ease of genome manipulation via genetic engineering techniques, their ability to correctly modify recombinant proteins while retaining biological activity and their simplicity for oral vaccine administration makes them ideal production and delivery vehicles for mucosal vaccination (Fuchs and Gonsalves 2007; Horn, Woodard, and Howard 2004; Streatfield 2006). Further, the federal government has confirmed the safety of transgenic plants for human consumption as no human toxicity has been detected since their first appearance two decades ago (Konig et al. 2004; Flachowsky, Chesson, and Aulrich 2005). Having completed phase 3 trials, several plant synthesized pharmaceuticals have already emerged into the marketplace (Horn, Woodard, and Howard 2004). In contrast to injected vaccines that stimulate only IgG antibody production, plant based vaccines stimulate both IgA and IgG antibody biosynthesis, protecting mucosal epithelia as well as blood perfused tissues. Further, plants do not become infected with animal pathogens, and since they are delivered by the digestive tract, they eliminate needle based injuries and cross infection. In terms of stimulating immunity, heterologous plant prime-boost vaccination regimes were shown to generate high levels of antibody protection in mice (Webster et al. 2006). Important to this review, plant vaccines have also been shown to suppress autoimmune diseases (Arakawa, Chong, and Langridge 1998; von Herrath and Whitton 2000). The addition of immunomodulators to autoantigens in prime-boost regimens was shown to significantly enhance immunological suppression of autoimmunity and allergy (Ulmer, Wahren, and Liu 2006, 2006). Alternatively, virus delivered CTB::INS and CTB::GAD fusion genes expressed in primate and human cells were shown to partially suppress insulitis and hyperglycemia in NOD mice providing the option for development of virus prime-plant boost strategies for enhanced suppression of autoimmunity (Denes et al. 2005; Denes et al. 2006). Thus, in addition to providing nutrition, transgenic plant tissues can provide proteins that both suppress diabetes autoimmunity and serve as production and delivery vehicles for multi-component vaccines that can suppress autoimmunity.

\section{Conclusions}

A variety of bacterial and plant enterotoxin B subunit immunomodulatory molecules linked to diabetes autoantigens were shown to safely generate substantial increases in immunological tolerance in vaccinated prediabetic mice. Additional evidence from NOD mouse vaccination experiments showed that this multifactorial vaccination strategy in 
combination with the anti-inflammatory cytokine IL-10 is both effective and safe for durable suppression of chronic insulitis responsible for type 1 diabetes onset. Recent ex vivo monocyte derived DC - CTB::autoantigen fusion protein inoculation experiments showed that enhancement of immunological tolerance correlated with vaccine suppression of DC biosynthesis of co-stimulatory factors CD86, CD83 and CD80. In addition, vaccine inoculated DCs were shown to further suppress diabetes autoimmunity by down-regulating inflammatory cytokine IL-12 and IL-6 secretion and up-regulating secretion of the antiinflammatory cytokine IL-10. In future experiments, incubation of adjuvant-autoantigen inoculated DCs with naïve Th0 lymphocytes will determine the degree to which CTBautoantigen fusion proteins can stimulate naïve Th0 lymphocyte development into antiinflammatory Th2 or regulatory $\mathrm{T}$ cells. Further, these experiments may also establish whether CTB adjuvant-autoantigen fusion proteins suppress diabetes autoimmunity by enhancing DC inhibition of autoreactive Th1 or Th17 lymphocyte development.

\section{References}

Afzali, B., G. Lombardi, R. I. Lechler, and G. M. Lord. 2007. The role of T helper 17 (Th17) and regulatory $\mathrm{T}$ cells (Treg) in human organ transplantation and autoimmune disease. Clin Exp Immunol 148 (1):32-46.

Akbari, O., R. H. DeKruyff, and D. T. Umetsu. 2001. Pulmonary dendritic cells producing IL-10 mediate tolerance induced by respiratory exposure to antigen. Nat Immunol 2 (8):725-31.

Akbari, O., G. J. Freeman, E. H. Meyer, E. A. Greenfield, T. T. Chang, A. H. Sharpe, G. Berry, R. H. DeKruyff, and D. T. Umetsu. 2002. Antigen-specific regulatory T cells develop via the ICOS-ICOS-ligand pathway and inhibit allergen-induced airway hyperreactivity. Nat Med 8 (9):1024-32.

Akerblom HK, Vaarala O, Hyoty H, Ilonen J, Knip M. . 2002. Environmental factors in the etiology of type 1 diabetes. Am J Med Genet. 115 (1):18-29.

Apostolou, I., and H. von Boehmer. 2004. In vivo instruction of suppressor commitment in naive T cells. J Exp Med 199 (10):1401-8.

Arakawa, T., D. K. Chong, and W. H. Langridge. 1998. Efficacy of a food plant-based oral cholera toxin B subunit vaccine. Nat Biotechnol 16 (3):292-7.

Arakawa, T., J. Yu, D. K. Chong, J. Hough, P. C. Engen, and W. H. Langridge. 1998. A plantbased cholera toxin B subunit-insulin fusion protein protects against the development of autoimmune diabetes. Nat Biotechnol 16 (10):934-8.

Aspord, C., C. Czerkinsky, A. Durand, A. Stefanutti, and C. Thivolet. 2002. alpha4 integrins and L-selectin differently orchestrate T-cell activity during diabetes prevention following oral administration of CTB-insulin. J Autoimmun 19 (4):223-32.

Atkinson, M. A., M. A. Bowman, L. Campbell, B. L. Darrow, D. L. Kaufman, and N. K. Maclaren. 1994. Cellular immunity to a determinant common to glutamate decarboxylase and coxsackie virus in insulin-dependent diabetes. J Clin Invest 94 (5):2125-9.

Bach, J. F. 2005. A Toll-like trigger for autoimmune disease. Nat Med 11 (2):120-1.

Baekkeskov, S., H. J. Aanstoot, S. Christgau, A. Reetz, M. Solimena, M. Cascalho, F. Folli, H. Richter-Olesen, and P. De Camilli. 1990. Identification of the 64K autoantigen in insulin-dependent diabetes as the GABA-synthesizing enzyme glutamic acid decarboxylase. Nature 347 (6289):151-6. 
Battaglia, M., A. Stabilini, E. Draghici, B. Migliavacca, S. Gregori, E. Bonifacio, and M. G. Roncarolo. 2006. Induction of tolerance in type 1 diabetes via both CD4+CD25+ T regulatory cells and T regulatory type 1 cells. Diabetes 55 (6):1571-80.

Bending, D., H. De La Pena, M. Veldhoen, J. M. Phillips, C. Uyttenhove, B. Stockinger, and A. Cooke. 2009. Highly purified Th17 cells from BDC2.5NOD mice convert into Th1-like cells in NOD/SCID recipient mice. J Clin Invest 119 (3):565-72.

Bergerot, I., C. Ploix, J. Petersen, V. Moulin, C. Rask, N. Fabien, M. Lindblad, A. Mayer, C. Czerkinsky, J. Holmgren, and C. Thivolet. 1997. A cholera toxoid-insulin conjugate as an oral vaccine against spontaneous autoimmune diabetes. Proc Natl Acad Sci U S A 94 (9):4610-4.

Bitar, D. M., and C. C. Whitacre. 1988. Suppression of experimental autoimmune encephalomyelitis by the oral administration of myelin basic protein. Cell Immunol $112(2): 364-70$.

Bluestone, J. A., and A. K. Abbas. 2003. Natural versus adaptive regulatory T cells. Nat Rev Immunol 3 (3):253-7.

Bresson, D., L. Togher, E. Rodrigo, Y. Chen, J. A. Bluestone, K. C. Herold, and M. von Herrath. 2006. Anti-CD3 and nasal proinsulin combination therapy enhances remission from recent-onset autoimmune diabetes by inducing Tregs. J Clin Invest 116 (5):1371-81.

Cardell, S. L. 2006. The natural killer T lymphocyte: a player in the complex regulation of autoimmune diabetes in non-obese diabetic mice. Clin Exp Immunol 143 (2):194-202.

Chaillous, L., H. Lefevre, C. Thivolet, C. Boitard, N. Lahlou, C. Atlan-Gepner, B. Bouhanick, A. Mogenet, M. Nicolino, J. C. Carel, P. Lecomte, R. Marechaud, P. Bougneres, B. Charbonnel, and P. Sai. 2000. Oral insulin administration and residual beta-cell function in recent-onset type 1 diabetes: a multicentre randomised controlled trial. Diabete Insuline Orale group. Lancet 356 (9229):545-9.

Cua, D. J., J. Sherlock, Y. Chen, C. A. Murphy, B. Joyce, B. Seymour, L. Lucian, W. To, S. Kwan, T. Churakova, S. Zurawski, M. Wiekowski, S. A. Lira, D. Gorman, R. A. Kastelein, and J. D. Sedgwick. 2003. Interleukin-23 rather than interleukin-12 is the critical cytokine for autoimmune inflammation of the brain. Nature 421 (6924):744-8.

Dai, Y. D., G. Carayanniotis, and E. Sercarz. 2005. Antigen processing by autoreactive B cells promotes determinant spreading. Cell Mol Immunol 2 (3):169-75.

De Smedt, T., M. Van Mechelen, G. De Becker, J. Urbain, O. Leo, and M. Moser. 1997. Effect of interleukin-10 on dendritic cell maturation and function. Eur J Immunol 27 (5):1229-35.

de Waal Malefyt, R., J. Abrams, B. Bennett, C. G. Figdor, and J. E. de Vries. 1991. Interleukin 10(IL-10) inhibits cytokine synthesis by human monocytes: an autoregulatory role of IL-10 produced by monocytes. J Exp Med 174 (5):1209-20.

Delovitch, T. L., and B. Singh. 1997. The nonobese diabetic mouse as a model of autoimmune diabetes: immune dysregulation gets the NOD. Immunity 7 (6):727-38.

Denes, B., I. Fodor, and W. H. Langridge. 2010. Autoantigens plus interleukin-10 suppress diabetes autoimmunity. Diabetes Technol Ther 12 (8):649-61.

Denes, B., V. Krausova, N. Fodor, T. Timiryasova, D. Henderson, J. Hough, J. Yu, I. Fodor, and W. H. Langridge. 2005. Protection of NOD mice from type 1 diabetes after oral inoculation with vaccinia viruses expressing adjuvanted islet autoantigens. J Immunother 28 (5):438-48. 
Denes, B., J. Yu, N. Fodor, Z. Takatsy, I. Fodor, and W. H. Langridge. 2006. Suppression of hyperglycemia in NOD mice after inoculation with recombinant vaccinia viruses. Mol Biotechnol 34 (3):317-27.

Devaraj, S., A. T. Cheung, I. Jialal, S. C. Griffen, D. Nguyen, N. Glaser, and T. Aoki. 2007. Evidence of increased inflammation and microcirculatory abnormalities in patients with type 1 diabetes and their role in microvascular complications. Diabetes 56 (11):2790-6.

Di Lorenzo, T. P., M. Peakman, and B. O. Roep. 2007. Translational mini-review series on type 1 diabetes: Systematic analysis of T cell epitopes in autoimmune diabetes. Clin Exp Immunol 148 (1):1-16.

Donnelly, R. P., H. Dickensheets, and D. S. Finbloom. 1999. The interleukin-10 signal transduction pathway and regulation of gene expression in mononuclear phagocytes. J Interferon Cytokine Res 19 (6):563-73.

Duerr, R. H., K. D. Taylor, S. R. Brant, J. D. Rioux, M. S. Silverberg, M. J. Daly, A. H. Steinhart, C. Abraham, M. Regueiro, A. Griffiths, T. Dassopoulos, A. Bitton, H. Yang, S. Targan, L. W. Datta, E. O. Kistner, L. P. Schumm, A. T. Lee, P. K. Gregersen, M. M. Barmada, J. I. Rotter, D. L. Nicolae, and J. H. Cho. 2006. A genome-wide association study identifies IL23R as an inflammatory bowel disease gene. Science 314 (5804):1461-3.

Ehrenstein, M. R., J. G. Evans, A. Singh, S. Moore, G. Warnes, D. A. Isenberg, and C. Mauri. 2004. Compromised function of regulatory $\mathrm{T}$ cells in rheumatoid arthritis and reversal by anti-TNFalpha therapy. J Exp Med 200 (3):277-85.

Elliott, J. F., H. Y. Qin, S. Bhatti, D. K. Smith, R. K. Singh, T. Dillon, J. Lauzon, and B. Singh. 1994. Immunization with the larger isoform of mouse glutamic acid decarboxylase (GAD67) prevents autoimmune diabetes in NOD mice. Diabetes 43 (12):1494-9.

Enk, A. H. 2005. Dendritic cells in tolerance induction. Immunol Lett 99 (1):8-11.

Eriksson, K., and J. Holmgren. 2002. Recent advances in mucosal vaccines and adjuvants. Curr Opin Immunol 14 (5):666-72.

Ferwerda, G., S. E. Girardin, B. J. Kullberg, L. Le Bourhis, D. J. de Jong, D. M. Langenberg, R. van Crevel, G. J. Adema, T. H. Ottenhoff, J. W. Van der Meer, and M. G. Netea. 2005. NOD2 and toll-like receptors are nonredundant recognition systems of Mycobacterium tuberculosis. PLoS Pathog 1 (3):279-85.

Filippi, C., D. Bresson, and M. von Herrath. 2005. Antigen-specific induction of regulatory T cells for type 1 diabetes therapy. Int Rev Immunol 24 (5-6):341-60.

Flachowsky, G., A. Chesson, and K. Aulrich. 2005. Animal nutrition with feeds from genetically modified plants. Arch Anim Nutr 59 (1):1-40.

Fontenot, J. D., M. A. Gavin, and A. Y. Rudensky. 2003. Foxp3 programs the development and function of CD4+CD25+ regulatory T cells. Nat Immunol 4 (4):330-6.

Fuchs, M., and D. Gonsalves. 2007. Safety of virus-resistant transgenic plants two decades after their introduction: lessons from realistic field risk assessment studies. Annu Rev Phytopathol 45:173-202.

Gale, E. A. 2002. The rise of childhood type 1 diabetes in the 20th century. Diabetes 51 (12):3353-61.

George-Chandy, A., K. Eriksson, M. Lebens, I. Nordstrom, E. Schon, and J. Holmgren. 2001. Cholera toxin B subunit as a carrier molecule promotes antigen presentation and 
increases CD40 and CD86 expression on antigen-presenting cells. Infect Immun 69 (9):5716-25.

Goudy, K. S., B. R. Burkhardt, C. Wasserfall, S. Song, M. L. Campbell-Thompson, T. Brusko, M. A. Powers, M. J. Clare-Salzler, E. S. Sobel, T. M. Ellis, T. R. Flotte, and M. A. Atkinson. 2003. Systemic overexpression of IL-10 induces CD4+CD25+ cell populations in vivo and ameliorates type 1 diabetes in nonobese diabetic mice in a dose-dependent fashion. J Immunol 171 (5):2270-8.

Goudy, K., S. Song, C. Wasserfall, Y. C. Zhang, M. Kapturczak, A. Muir, M. Powers, M. Scott-Jorgensen, M. Campbell-Thompson, J. M. Crawford, T. M. Ellis, T. R. Flotte, and M. A. Atkinson. 2001. Adeno-associated virus vector-mediated IL-10 gene delivery prevents type 1 diabetes in NOD mice. Proc Natl Acad Sci U S A 98 (24):13913-8.

Groux, H., F. Cottrez, M. Rouleau, S. Mauze, S. Antonenko, S. Hurst, T. McNeil, M. Bigler, M. G. Roncarolo, and R. L. Coffman. 1999. A transgenic model to analyze the immunoregulatory role of IL-10 secreted by antigen-presenting cells. J Immunol 162 (3):1723-9.

Grutz, G. 2005. New insights into the molecular mechanism of interleukin-10-mediated immunosuppression. J Leukoc Biol 77 (1):3-15.

Hajishengallis, G., S. Arce, C. M. Gockel, T. D. Connell, and M. W. Russell. 2005. Immunomodulation with enterotoxins for the generation of secretory immunity or tolerance: applications for oral infections. J Dent Res 84 (12):1104-16.

Han, B., P. Serra, J. Yamanouchi, A. Amrani, J. F. Elliott, P. Dickie, T. P. Dilorenzo, and P. Santamaria. 2005. Developmental control of CD8 T cell-avidity maturation in autoimmune diabetes. J Clin Invest 115 (7):1879-87.

Harizi, H., and N. Gualde. 2006. Pivotal role of PGE2 and IL-10 in the cross-regulation of dendritic cell-derived inflammatory mediators. Cell Mol Immunol 3 (4):271-7.

Haverkos, H. W., N. Battula, D. P. Drotman, and O. M. Rennert. 2003. Enteroviruses and type 1 diabetes mellitus. Biomed Pharmacother 57 (9):379-85.

Higgins, P. J., and H. L. Weiner. 1988. Suppression of experimental autoimmune encephalomyelitis by oral administration of myelin basic protein and its fragments. J Immunol 140 (2):440-5.

Holmgren, J., and C. Czerkinsky. 2005. Mucosal immunity and vaccines. Nat Med 11 (4 Suppl):S45-53.

Holmgren, J., C. Czerkinsky, N. Lycke, and A. M. Svennerholm. 1994. Strategies for the induction of immune responses at mucosal surfaces making use of cholera toxin B subunit as immunogen, carrier, and adjuvant. Am J Trop Med Hyg 50 (5 Suppl):4254.

Hommann, M., U. Schotte, K. K. Richter, U. Moller, R. Basciani, and J. Scheele. 2001. [HELLP Syndrome as an indication for liver transplantation]. Gynakol Geburtshilfliche Rundsch 41 (1):8-11.

Hori, S., T. Nomura, and S. Sakaguchi. 2003. Control of regulatory T cell development by the transcription factor Foxp3. Science 299 (5609):1057-61.

Hori, S., and S. Sakaguchi. 2004. Foxp3: a critical regulator of the development and function of regulatory T cells. Microbes Infect 6 (8):745-51.

Horn, M. E., S. L. Woodard, and J. A. Howard. 2004. Plant molecular farming: systems and products. Plant Cell Rep 22 (10):711-20. 
Huang, J. B., Y. Takeda, Y. Araki, F. Sendo, and H. R. Petty. 2004. Molecular proximity of complement receptor type 3 (CR3) and the glycosylphosphatidylinositol-linked protein GPI-80 on neutrophils: effects of cell adherence, exogenous saccharides, and lipid raft disrupting agents. Mol Immunol 40 (17):1249-56.

Hutchings, P., and A. Cooke. 1998. Protection from insulin dependent diabetes mellitus afforded by insulin antigens in incomplete Freund's adjuvant depends on route of administration. J Autoimmun 11 (2):127-30.

International, Juvenile Diabetes Research Foundation, ed. 2005. KRC Research for JDRF. New York.

Itano, A. A., S. J. McSorley, R. L. Reinhardt, B. D. Ehst, E. Ingulli, A. Y. Rudensky, and M. K. Jenkins. 2003. Distinct dendritic cell populations sequentially present antigen to CD4 T cells and stimulate different aspects of cell-mediated immunity. Immunity 19 (1):47-57.

Iwasaki, A., and B. L. Kelsall. 2000. Localization of distinct Peyer's patch dendritic cell subsets and their recruitment by chemokines macrophage inflammatory protein (MIP)-3alpha, MIP-3beta, and secondary lymphoid organ chemokine. J Exp Med 191 (8):1381-94.

Jaeckel, E., L. Klein, N. Martin-Orozco, and H. von Boehmer. 2003. Normal incidence of diabetes in NOD mice tolerant to glutamic acid decarboxylase. J Exp Med 197 (12):1635-44.

Jaeckel, E., M. A. Lipes, and H. von Boehmer. 2004. Recessive tolerance to preproinsulin 2 reduces but does not abolish type 1 diabetes. Nat Immunol 5 (10):1028-35.

Jun, H. S., Y. H. Chung, J. Han, A. Kim, S. S. Yoo, R. S. Sherwin, and J. W. Yoon. 2002. Prevention of autoimmune diabetes by immunogene therapy using recombinant vaccinia virus expressing glutamic acid decarboxylase. Diabetologia 45 (5):668-76.

Jun, H. S., L. Y. Khil, and J. W. Yoon. 2002. Role of glutamic acid decarboxylase in the pathogenesis of type 1 diabetes. Cell Mol Life Sci 59 (11):1892-901.

Jun, H. S., and J. W. Yoon. 2001. The role of viruses in type I diabetes: two distinct cellular and molecular pathogenic mechanisms of virus-induced diabetes in animals. Diabetologia 44 (3):271-85.

Kaisho, T., and S. Akira. 2002. Toll-like receptors as adjuvant receptors. Biochim Biophys Acta 1589 (1):1-13.

Kanneganti, T. D., M. Lamkanfi, Y. G. Kim, G. Chen, J. H. Park, L. Franchi, P. Vandenabeele, and G. Nunez. 2007. Pannexin-1-mediated recognition of bacterial molecules activates the cryopyrin inflammasome independent of Toll-like receptor signaling. Immunity 26 (4):433-43.

Kelsen, J., C. L. Hvas, J. Agnholt, and J. F. Dahlerup. 2006. [CD4 + CD25 + regulatory T cells and their importance to human illnesses]. Ugeskr Laeger 168 (1):32-7.

Kent, S. C., Y. Chen, L. Bregoli, S. M. Clemmings, N. S. Kenyon, C. Ricordi, B. J. Hering, and D. A. Hafler. 2005. Expanded T cells from pancreatic lymph nodes of type 1 diabetic subjects recognize an insulin epitope. Nature 435 (7039):224-8.

Kim, J. J., J. S. Yang, L. K. Nottingham, W. Tang, K. Dang, K. H. Manson, M. S. Wyand, D. M. Wilson, and D. B. Weiner. 2001. Induction of immune responses and safety profiles in rhesus macaques immunized with a DNA vaccine expressing human prostate specific antigen. Oncogene 20 (33):4497-506. 
King, C., J. Davies, R. Mueller, M. S. Lee, T. Krahl, B. Yeung, E. O'Connor, and N. Sarvetnick. 1998. TGF-beta1 alters APC preference, polarizing islet antigen responses toward a Th2 phenotype. Immunity 8 (5):601-13.

Kobayashi, T., S. Tanaka, N. Harii, K. Aida, H. Shimura, M. Ohmori, M. Kanesige, A. Shimada, and T. Maruyama. 2006. Immunopathological and genetic features in slowly progressive insulin-dependent diabetes mellitus and latent autoimmune diabetes in adults. Ann N Y Acad Sci 1079:60-6.

Kojo, S., K. Seino, M. Harada, H. Watarai, H. Wakao, T. Uchida, T. Nakayama, and M. Taniguchi. 2005. Induction of regulatory properties in dendritic cells by Valpha14 NKT cells. J Immunol 175 (6):3648-55.

Konig, A., A. Cockburn, R. W. Crevel, E. Debruyne, R. Grafstroem, U. Hammerling, I. Kimber, I. Knudsen, H. A. Kuiper, A. A. Peijnenburg, A. H. Penninks, M. Poulsen, M. Schauzu, and J. M. Wal. 2004. Assessment of the safety of foods derived from genetically modified (GM) crops. Food Chem Toxicol 42 (7):1047-88.

Kretschmer, K., I. Apostolou, D. Hawiger, K. Khazaie, M. C. Nussenzweig, and H. von Boehmer. 2005. Inducing and expanding regulatory $\mathrm{T}$ cell populations by foreign antigen. Nat Immunol 6 (12):1219-27.

Langrish, C. L., Y. Chen, W. M. Blumenschein, J. Mattson, B. Basham, J. D. Sedgwick, T. McClanahan, R. A. Kastelein, and D. J. Cua. 2005. IL-23 drives a pathogenic T cell population that induces autoimmune inflammation. J Exp Med 201 (2):233-40.

Lavelle, E. C., E. McNeela, M. E. Armstrong, O. Leavy, S. C. Higgins, and K. H. Mills. 2003. Cholera toxin promotes the induction of regulatory $\mathrm{T}$ cells specific for bystander antigens by modulating dendritic cell activation. J Immunol 171 (5):2384-92.

Leceta, J., R. P. Gomariz, C. Martinez, C. Abad, D. Ganea, and M. Delgado. 2000. Receptors and transcriptional factors involved in the anti-inflammatory activity of VIP and PACAP. Ann N Y Acad Sci 921:92-102.

Levings, M. K., S. Gregori, E. Tresoldi, S. Cazzaniga, C. Bonini, and M. G. Roncarolo. 2005. Differentiation of Tr1 cells by immature dendritic cells requires IL-10 but not CD25+CD4+ Tr cells. Blood 105 (3):1162-9.

Li, T. K., and B. S. Fox. 1996. Cholera toxin B subunit binding to an antigen-presenting cell directly co-stimulates cytokine production from a $\mathrm{T}$ cell clone. Int Immunol 8 (12):1849-56.

Li, Y. Y., Y. Yang, M. Bao, C. K. Edwards, 3rd, and J. R. Parnes. 2006. Mouse splenic B lymphocyte activation using different activation stimuli induces in vitro splicing of tumor necrosis factor-alpha nuclear pre-mRNA. Mol Immunol 43 (6):613-22.

Libby, P., D. M. Nathan, K. Abraham, J. D. Brunzell, J. E. Fradkin, S. M. Haffner, W. Hsueh, M. Rewers, B. T. Roberts, P. J. Savage, S. Skarlatos, M. Wassef, and C. RabadanDiehl. 2005. Report of the National Heart, Lung, and Blood Institute-National Institute of Diabetes and Digestive and Kidney Diseases Working Group on Cardiovascular Complications of Type 1 Diabetes Mellitus. Circulation 111 (25):3489-93.

Lindley, S., C. M. Dayan, A. Bishop, B. O. Roep, M. Peakman, and T. I. Tree. 2005. Defective suppressor function in $\mathrm{CD} 4(+) \mathrm{CD} 25(+)$ T-cells from patients with type 1 diabetes. Diabetes 54 (1):92-9.

Liu, L., Z. Xu, R. C. Fuhlbrigge, V. Pena-Cruz, J. Lieberman, and T. S. Kupper. 2005. Vaccinia virus induces strong immunoregulatory cytokine production in healthy human 
epidermal keratinocytes: a novel strategy for immune evasion. J Virol 79 (12):736370 .

Liu, Z., K. Geboes, P. Hellings, P. Maerten, H. Heremans, P. Vandenberghe, L. Boon, P. van Kooten, P. Rutgeerts, and J. L. Ceuppens. 2001. B7 interactions with CD28 and CTLA-4 control tolerance or induction of mucosal inflammation in chronic experimental colitis. J Immunol 167 (3):1830-8.

Lodinova-Zadnikova, R., L. Prokesova, H. Tlaskalova, I. Kocourkova, J. Zizka, and Z. Stranak. 2004. [Influence of oral colonization with probiotic E. coli strain after birth on frequency of recurrent infections, allergy and development of some immunologic parameters. Long-term studies]. Ceska Gynekol 69 Suppl 1:91-7.

Lutz, M. B., and G. Schuler. 2002. Immature, semi-mature and fully mature dendritic cells: which signals induce tolerance or immunity? Trends Immunol 23 (9):445-9.

Lycke, N. 2004. ADP-ribosylating bacterial enzymes for the targeted control of mucosal tolerance and immunity. Ann N Y Acad Sci 1029:193-208.

Maioli, M., L. Puddu, and G. M. Pes. 2006. [Latent autoimmune diabetes in adults]. Clin Ter 157 (1):69-78.

Makino, S., K. Kunimoto, Y. Muraoka, Y. Mizushima, K. Katagiri, and Y. Tochino. 1980. Breeding of a non-obese, diabetic strain of mice. Jikken Dobutsu 29 (1):1-13.

Marinaro, M., H. F. Staats, T. Hiroi, R. J. Jackson, M. Coste, P. N. Boyaka, N. Okahashi, M. Yamamoto, H. Kiyono, H. Bluethmann, K. Fujihashi, and J. R. McGhee. 1995. Mucosal adjuvant effect of cholera toxin in mice results from induction of $\mathrm{T}$ helper 2 (Th2) cells and IL-4. J Immunol 155 (10):4621-9.

MartIn-Fontecha, A., S. Sebastiani, U. E. Hopken, M. Uguccioni, M. Lipp, A. Lanzavecchia, and F. Sallusto. 2003. Regulation of dendritic cell migration to the draining lymph node: impact on T lymphocyte traffic and priming. J Exp Med 198 (4):615-21.

Mastrangelo, M. J., H. C. Maguire, Jr., L. C. Eisenlohr, C. E. Laughlin, C. E. Monken, P. A. McCue, A. J. Kovatich, and E. C. Lattime. 1999. Intratumoral recombinant GM-CSFencoding virus as gene therapy in patients with cutaneous melanoma. Cancer Gene Ther 6 (5):409-22.

Mensah-Brown, E. P., A. Shahin, M. Al-Shamisi, X. Wei, and M. L. Lukic. 2006. IL-23 leads to diabetes induction after subdiabetogenic treatment with multiple low doses of streptozotocin. Eur J Immunol 36 (1):216-23.

Mensah-Brown, E. P., A. Shahin, M. Al-Shamsi, and M. L. Lukic. 2006. New members of the interleukin-12 family of cytokines: IL-23 and IL-27 modulate autoimmune diabetes. Ann N Y Acad Sci 1079:157-60.

Millington, O. R., A. M. Mowat, and P. Garside. 2004. Induction of bystander suppression by feeding antigen occurs despite normal clonal expansion of the bystander $\mathrm{T}$ cell population. J Immunol 173 (10):6059-64.

Minderhoud, I. M., M. Samsom, and B. Oldenburg. 2007. Crohn's disease, fatigue, and infliximab: is there a role for cytokines in the pathogenesis of fatigue? World J Gastroenterol 13 (14):2089-93.

- - - 2007. What predicts mucosal inflammation in Crohn's disease patients? Inflamm Bowel Dis 13 (12):1567-72.

Misra, N., J. Bayry, S. Lacroix-Desmazes, M. D. Kazatchkine, and S. V. Kaveri. 2004. Cutting edge: human $\mathrm{CD} 4+\mathrm{CD} 25+\mathrm{T}$ cells restrain the maturation and antigen-presenting function of dendritic cells. J Immunol 172 (8):4676-80. 
Moore, K. W., A. O'Garra, R. de Waal Malefyt, P. Vieira, and T. R. Mosmann. 1993. Interleukin-10. Annu Rev Immunol 11:165-90.

Moore, K. W., P. Vieira, D. F. Fiorentino, M. L. Trounstine, T. A. Khan, and T. R. Mosmann. 1990. Homology of cytokine synthesis inhibitory factor (IL-10) to the Epstein-Barr virus gene BCRFI. Science 248 (4960):1230-4.

Mordes, J. P., D. L. Guberski, J. H. Leif, B. A. Woda, J. F. Flanagan, D. L. Greiner, E. H. Kislauskis, and R. S. Tirabassi. 2005. LEW.1WR1 rats develop autoimmune diabetes spontaneously and in response to environmental perturbation. Diabetes 54 (9):272733.

Moss, B. 1991. Vaccinia virus: a tool for research and vaccine development. Science 252 (5013):1662-7.

- - - 1996. Genetically engineered poxviruses for recombinant gene expression, vaccination, and safety. Proc Natl Acad Sci U S A 93 (21):11341-8.

Mostarica-Stojkovic, M. 2005. [Mechanisms of the induction of autoimmunity]. Srp Arh Celok Lek 133 Suppl 1:9-15.

Murphy, C. A., C. L. Langrish, Y. Chen, W. Blumenschein, T. McClanahan, R. A. Kastelein, J. D. Sedgwick, and D. J. Cua. 2003. Divergent pro- and antiinflammatory roles for IL23 and IL-12 in joint autoimmune inflammation. J Exp Med 198 (12):1951-7.

Nakae, S., A. Nambu, K. Sudo, and Y. Iwakura. 2003. Suppression of immune induction of collagen-induced arthritis in IL-17-deficient mice. J Immunol 171 (11):6173-7.

Nakayama, M., N. Abiru, H. Moriyama, N. Babaya, E. Liu, D. Miao, L. Yu, D. R. Wegmann, J. C. Hutton, J. F. Elliott, and G. S. Eisenbarth. 2005. Prime role for an insulin epitope in the development of type 1 diabetes in NOD mice. Nature 435 (7039):2203.

Nocentini, G., and C. Riccardi. 2005. GITR: a multifaceted regulator of immunity belonging to the tumor necrosis factor receptor superfamily. Eur J Immunol 35 (4):1016-22.

Oderup, C., L. Cederbom, A. Makowska, C. M. Cilio, and F. Ivars. 2006. Cytotoxic T lymphocyte antigen-4-dependent down-modulation of costimulatory molecules on dendritic cells in CD4+ CD25+ regulatory T-cell-mediated suppression. Immunology 118 (2):240-9.

Odumosu, O., K. Payne, I. Baez, J. Jutzy, N. Wall, and W. Langridge. 2010. Suppression of dendritic cell activation by diabetes autoantigens linked to the cholera toxin $\mathrm{B}$ subunit. Immunobiology.

Okusawa, T., M. Fujita, J. Nakamura, T. Into, M. Yasuda, A. Yoshimura, Y. Hara, A. Hasebe, D. T. Golenbock, M. Morita, Y. Kuroki, T. Ogawa, and K. Shibata. 2004. Relationship between structures and biological activities of mycoplasmal diacylated lipopeptides and their recognition by toll-like receptors 2 and 6. Infect Immun 72 (3):1657-65.

Onengut-Gumuscu, S., and P. Concannon. 2002. Mapping genes for autoimmunity in humans: type 1 diabetes as a model. Immunol Rev 190:182-94.

Otteken, A., P. L. Earl, and B. Moss. 1996. Folding, assembly, and intracellular trafficking of the human immunodeficiency virus type 1 envelope glycoprotein analyzed with monoclonal antibodies recognizing maturational intermediates. J Virol 70 (6):340715. 
Palmer, J. P., C. M. Asplin, P. Clemons, K. Lyen, O. Tatpati, P. K. Raghu, and T. L. Paquette. 1983. Insulin antibodies in insulin-dependent diabetics before insulin treatment. Science 222 (4630):1337-9.

Phipps, P. A., M. R. Stanford, J. B. Sun, B. G. Xiao, J. Holmgren, T. Shinnick, A. Hasan, Y. Mizushima, and T. Lehner. 2003. Prevention of mucosally induced uveitis with a HSP60-derived peptide linked to cholera toxin B subunit. Eur J Immunol 33 (1):22432.

Pulendran, B., P. Kumar, C. W. Cutler, M. Mohamadzadeh, T. Van Dyke, and J. Banchereau. 2001. Lipopolysaccharides from distinct pathogens induce different classes of immune responses in vivo. J Immunol 167 (9):5067-76.

Pulendran, B., J. L. Smith, G. Caspary, K. Brasel, D. Pettit, E. Maraskovsky, and C. R. Maliszewski. 1999. Distinct dendritic cell subsets differentially regulate the class of immune response in vivo. Proc Natl Acad Sci U S A 96 (3):1036-41.

Qin, H., C. A. Wilson, K. L. Roberts, B. J. Baker, X. Zhao, and E. N. Benveniste. 2006. IL-10 inhibits lipopolysaccharide-induced CD40 gene expression through induction of suppressor of cytokine signaling-3. J Immunol 177 (11):7761-71.

Qin, H. Y., M. W. Sadelain, C. Hitchon, J. Lauzon, and B. Singh. 1993. Complete Freund's adjuvant-induced $\mathrm{T}$ cells prevent the development and adoptive transfer of diabetes in nonobese diabetic mice. J Immunol 150 (5):2072-80.

Rastellini, C., L. Lu, C. Ricordi, T. E. Starzl, A. S. Rao, and A. W. Thomson. 1995. Granulocyte/macrophage colony-stimulating factor-stimulated hepatic dendritic cell progenitors prolong pancreatic islet allograft survival. Transplantation 60 (11):1366-70.

Rewers, M., J. M. Norris, G. S. Eisenbarth, H. A. Erlich, B. Beaty, G. Klingensmith, M. Hoffman, L. Yu, T. L. Bugawan, A. Blair, R. F. Hamman, M. Groshek, and R. S. McDuffie, Jr. 1996. Beta-cell autoantibodies in infants and toddlers without IDDM relatives: diabetes autoimmunity study in the young (DAISY). J Autoimmun 9 (3):405-10.

Rissoan, M. C., V. Soumelis, N. Kadowaki, G. Grouard, F. Briere, R. de Waal Malefyt, and Y. J. Liu. 1999. Reciprocal control of $\mathrm{T}$ helper cell and dendritic cell differentiation. Science 283 (5405):1183-6.

Robinson, B. W., S. A. Mukherjee, A. Davidson, S. Morey, A. W. Musk, I. Ramshaw, D. Smith, R. Lake, T. Haenel, M. Garlepp, J. Marley, C. Leong, I. Caminschi, and B. Scott. 1998. Cytokine gene therapy or infusion as treatment for solid human cancer. J Immunother 21 (3):211-7.

Robinson, C. P., J. Cornelius, D. E. Bounous, H. Yamamoto, M. G. Humphreys-Beher, and A. B. Peck. 1998. Characterization of the changing lymphocyte populations and cytokine expression in the exocrine tissues of autoimmune NOD mice. Autoimmunity 27 (1):29-44.

Romagnani, S. 1998. The Th1/Th2 paradigm and allergic disorders. Allergy 53 (46 Suppl):125 .

Romagnani, S., M. Kapsenberg, A. Radbruch, and L. Adorini. 1998. Th1 and Th2 cells. Res Immunol 149 (9):871-3.

Roncarolo, M. G., R. Bacchetta, C. Bordignon, S. Narula, and M. K. Levings. 2001. Type 1 T regulatory cells. Immunol Rev 182:68-79. 
Sakaguchi, S. 2005. Naturally arising Foxp3-expressing CD25+CD4+ regulatory T cells in immunological tolerance to self and non-self. Nat Immunol 6 (4):345-52.

Sakaguchi, S., and N. Sakaguchi. 2005. Regulatory T cells in immunologic self-tolerance and autoimmune disease. Int Rev Immunol 24 (3-4):211-26.

Sakaguchi, S., N. Sakaguchi, M. Asano, M. Itoh, and M. Toda. 1995. Immunologic selftolerance maintained by activated T cells expressing IL-2 receptor alpha-chains (CD25). Breakdown of a single mechanism of self-tolerance causes various autoimmune diseases. J Immunol 155 (3):1151-64.

Schwimmbeck, P. L., T. Dyrberg, and M. B. Oldstone. 1988. Abrogation of diabetes in BB rats by acute virus infection. Association of viral-lymphocyte interactions. J Immunol 140 (10):3394-400.

Sela, M. 2006. Immunomodulatory vaccines against autoimmune diseases. Rejuvenation Res 9 (1):126-33.

Seong, S. Y., and P. Matzinger. 2004. Hydrophobicity: an ancient damage-associated molecular pattern that initiates innate immune responses. Nat Rev Immunol 4 (6):469-78.

Seyfert-Margolis, V., T. D. Gisler, A. L. Asare, R. S. Wang, H. M. Dosch, B. Brooks-Worrell, G. S. Eisenbarth, J. P. Palmer, C. J. Greenbaum, S. E. Gitelman, G. T. Nepom, J. A. Bluestone, and K. C. Herold. 2006. Analysis of T-cell assays to measure autoimmune responses in subjects with type 1 diabetes: results of a blinded controlled study. Diabetes 55 (9):2588-94.

Shen, X., and K. E. Bornfeldt. 2007. Mouse models for studies of cardiovascular complications of type 1 diabetes. Ann N Y Acad Sci 1103:202-17.

Shinomiya, M., S. M. Fazle Akbar, H. Shinomiya, and M. Onji. 1999. Transfer of dendritic cells (DC) ex vivo stimulated with interferon-gamma (IFN-gamma) downmodulates autoimmune diabetes in non-obese diabetic (NOD) mice. Clin Exp Immunol 117 (1):38-43.

Shreedhar, V. K., B. L. Kelsall, and M. R. Neutra. 2003. Cholera toxin induces migration of dendritic cells from the subepithelial dome region to T- and B-cell areas of Peyer's patches. Infect Immun 71 (1):504-9.

Sica, A., A. Saccani, B. Bottazzi, N. Polentarutti, A. Vecchi, J. van Damme, and A. Mantovani. 2000. Autocrine production of IL-10 mediates defective IL-12 production and NF-kappa B activation in tumor-associated macrophages. J Immunol 164 (2):762-7.

Silveira, P. A., and S. T. Grey. 2006. B cells in the spotlight: innocent bystanders or major players in the pathogenesis of type 1 diabetes. Trends Endocrinol Metab 17 (4):128-35.

Slavin, A. J., R. Maron, and H. L. Weiner. 2001. Mucosal administration of IL-10 enhances oral tolerance in autoimmune encephalomyelitis and diabetes. Int Immunol 13 (6):825-33.

Song, F., I. E. Gienapp, T. Shawler, Z. Guan, and C. C. Whitacre. 2004. The thymus plays a role in oral tolerance induction in experimental autoimmune encephalomyelitis. Ann N Y Acad Sci 1029:402-4.

Stassen, M., S. Fondel, T. Bopp, C. Richter, C. Muller, J. Kubach, C. Becker, J. Knop, A. H. Enk, S. Schmitt, E. Schmitt, and H. Jonuleit. 2004. Human CD25+ regulatory T cells: two subsets defined by the integrins alpha 4 beta 7 or alpha 4 beta 1 confer distinct suppressive properties upon CD4+ T helper cells. Eur J Immunol 34 (5):1303-11. 
Stassen, M., E. Schmitt, and H. Jonuleit. 2004. Human $\mathrm{CD}(4+) \mathrm{CD}(25+)$ regulatory T cells and infectious tolerance. Transplantation 77 (1 Suppl):S23-5.

Steinbrink, K., M. Wolfl, H. Jonuleit, J. Knop, and A. H. Enk. 1997. Induction of tolerance by IL-10-treated dendritic cells. J Immunol 159 (10):4772-80.

Steinman, R. M., and M. Pope. 2002. Exploiting dendritic cells to improve vaccine efficacy. J Clin Invest 109 (12):1519-26.

Stock, P., O. Akbari, G. Berry, G. J. Freeman, R. H. Dekruyff, and D. T. Umetsu. 2004. Induction of $\mathrm{T}$ helper type 1-like regulatory cells that express Foxp3 and protect against airway hyper-reactivity. Nat Immunol 5 (11):1149-56.

Streatfield, S. J. 2006. Mucosal immunization using recombinant plant-based oral vaccines. Methods 38 (2):150-7.

Sun, J. B., J. Holmgren, and C. Czerkinsky. 1994. Cholera toxin B subunit: an efficient transmucosal carrier-delivery system for induction of peripheral immunological tolerance. Proc Natl Acad Sci U S A 91 (23):10795-9.

Sun, J. B., C. Rask, T. Olsson, J. Holmgren, and C. Czerkinsky. 1996. Treatment of experimental autoimmune encephalomyelitis by feeding myelin basic protein conjugated to cholera toxin B subunit. Proc Natl Acad Sci U S A 93 (14):7196-201.

Sun, J. B., B. G. Xiao, M. Lindblad, B. L. Li, H. Link, C. Czerkinsky, and J. Holmgren. 2000. Oral administration of cholera toxin B subunit conjugated to myelin basic protein protects against experimental autoimmune encephalomyelitis by inducing transforming growth factor-beta-secreting cells and suppressing chemokine expression. Int Immunol 12 (10):1449-57.

Sutmuller, R. P., M. E. Morgan, M. G. Netea, O. Grauer, and G. J. Adema. 2006. Toll-like receptors on regulatory T cells: expanding immune regulation. Trends Immunol 27 (8):387-93.

Taams, L. S., and A. N. Akbar. 2005. Peripheral generation and function of CD4+CD25+ regulatory T cells. Curr Top Microbiol Immunol 293:115-31.

Takeda, K., T. Kaisho, and S. Akira. 2003. Toll-like receptors. Annu Rev Immunol 21:335-76.

Tang, Q., J. Y. Adams, A. J. Tooley, M. Bi, B. T. Fife, P. Serra, P. Santamaria, R. M. Locksley, M. F. Krummel, and J. A. Bluestone. 2006. Visualizing regulatory T cell control of autoimmune responses in nonobese diabetic mice. Nat Immunol 7 (1):83-92.

Tarbell, K. V., S. Yamazaki, K. Olson, P. Toy, and R. M. Steinman. 2004. CD25+ CD4+ T cells, expanded with dendritic cells presenting a single autoantigenic peptide, suppress autoimmune diabetes. J Exp Med 199 (11):1467-77.

Tatersall R. B., and Pyke, D.A. . 1972. Diabetes in identical twins. Lancet 2 (7787):1120-1125.

Thompson, H. S., and N. A. Staines. 1986. Gastric administration of type II collagen delays the onset and severity of collagen-induced arthritis in rats. Clin Exp Immunol 64 (3):581-6.

Tian, J., D. Zekzer, Y. Lu, H. Dang, and D. L. Kaufman. 2006. B cells are crucial for determinant spreading of $\mathrm{T}$ cell autoimmunity among beta cell antigens in diabetes-prone nonobese diabetic mice. J Immunol 176 (4):2654-61.

Tisch, R., and H. McDevitt. 1996. Insulin-dependent diabetes mellitus. Cell 85 (3):291-7.

Tracy, S., and K. M. Drescher. 2007. Coxsackievirus infections and NOD mice: relevant models of protection from, and induction of, type 1 diabetes. Ann N Y Acad Sci 1103:143-51. 
Trembleau, S., T. Germann, M. K. Gately, and L. Adorini. 1995. The role of IL-12 in the induction of organ-specific autoimmune diseases. Immunol Today 16 (8):383-6.

Tritt, M., E. Sgouroudis, E. d'Hennezel, A. Albanese, and C. A. Piccirillo. 2008. Functional waning of naturally occurring CD4+ regulatory T-cells contributes to the onset of autoimmune diabetes. Diabetes 57 (1):113-23.

Ulmer, J. B., B. Wahren, and M. A. Liu. 2006. DNA vaccines: recent technological and clinical advances. Discov Med 6 (33):109-12.

- - - 2006. Gene-based vaccines: recent technical and clinical advances. Trends Mol Med 12 (5):216-22.

Veldhoen, M., R. J. Hocking, C. J. Atkins, R. M. Locksley, and B. Stockinger. 2006. TGFbeta in the context of an inflammatory cytokine milieu supports de novo differentiation of IL-17-producing T cells. Immunity 24 (2):179-89.

Vendrame, F., A. Zappaterreno, and F. Dotta. 2004. Markers of beta cell function in type 1 diabetes mellitus. Minerva Med 95 (2):79-84.

Viglietta, V., C. Baecher-Allan, H. L. Weiner, and D. A. Hafler. 2004. Loss of functional suppression by CD4+CD25+ regulatory T cells in patients with multiple sclerosis. $J$ Exp Med 199 (7):971-9.

Vigouroux, S., E. Yvon, E. Biagi, and M. K. Brenner. 2004. Antigen-induced regulatory T cells. Blood 104 (1):26-33.

von Herrath, M. G., and J. L. Whitton. 2000. DNA vaccination to treat autoimmune diabetes. Ann Med 32 (5):285-92.

Walter, U., and P. Santamaria. 2005. CD8+ T cells in autoimmunity. Curr Opin Immunol 17 (6):624-31.

Watanabe, N., Y. H. Wang, H. K. Lee, T. Ito, W. Cao, and Y. J. Liu. 2005. Hassall's corpuscles instruct dendritic cells to induce CD4+CD25+ regulatory T cells in human thymus. Nature 436 (7054):1181-5.

Webster, D. E., S. D. Smith, R. J. Pickering, R. A. Strugnell, I. B. Dry, and S. L. Wesselingh. 2006. Measles virus hemagglutinin protein expressed in transgenic lettuce induces neutralising antibodies in mice following mucosal vaccination. Vaccine 24 (17):353844.

Weiner, H. L. 2001. Induction and mechanism of action of transforming growth factor-betasecreting Th3 regulatory cells. Immunol Rev 182:207-14.

Weiner, H. L., Z. J. Zhang, S. J. Khoury, A. Miller, A. al-Sabbagh, S. A. Brod, O. Lider, P. Higgins, R. Sobel, R. B. Nussenblatt, and et al. 1991. Antigen-driven peripheral immune tolerance. Suppression of organ-specific autoimmune diseases by oral administration of autoantigens. Ann N Y Acad Sci 636:227-32.

Wen, L., J. Peng, Z. Li, and F. S. Wong. 2004. The effect of innate immunity on autoimmune diabetes and the expression of Toll-like receptors on pancreatic islets. J Immunol 172 (5):3173-80.

Wilson, N. S., D. El-Sukkari, and J. A. Villadangos. 2004. Dendritic cells constitutively present self antigens in their immature state in vivo and regulate antigen presentation by controlling the rates of MHC class II synthesis and endocytosis. Blood 103 (6):2187-95.

Wucherpfennig, K. W., J. Zhang, C. Witek, M. Matsui, Y. Modabber, K. Ota, and D. A. Hafler. 1994. Clonal expansion and persistence of human $\mathrm{T}$ cells specific for an immunodominant myelin basic protein peptide. J Immunol 152 (11):5581-92. 
Yamaguchi, Y., H. Tsumura, M. Miwa, and K. Inaba. 1997. Contrasting effects of TGF-beta 1 and TNF-alpha on the development of dendritic cells from progenitors in mouse bone marrow. Stem Cells 15 (2):144-53.

Yang, S., W. Li, W. Liu, C. Gao, B. Zhou, S. Li, Y. Li, and Y. Kong. 2006. IL-10 gene modified dendritic cells induced antigen-specific tolerance in experimental autoimmune myocarditis. Clin Immunol 121 (1):63-73.

Yoon, J. W., and H. S. Jun. 2005. Autoimmune destruction of pancreatic beta cells. Am J Ther $12(6): 580-91$.

Yoon, J. W., H. S. Jun, and P. Santamaria. 1998. Cellular and molecular mechanisms for the initiation and progression of beta cell destruction resulting from the collaboration between macrophages and T cells. Autoimmunity 27 (2):109-22.

Yoon, S. I., N. J. Logsdon, F. Sheikh, R. P. Donnelly, and M. R. Walter. 2006. Conformational changes mediate interleukin-10 receptor 2 (IL-10R2) binding to IL-10 and assembly of the signaling complex. J Biol Chem 281 (46):35088-96.

Zhang, Z. J., L. Davidson, G. Eisenbarth, and H. L. Weiner. 1991. Suppression of diabetes in nonobese diabetic mice by oral administration of porcine insulin. Proc Natl Acad Sci U S A 88 (22):10252-6.

Zheng, Y., D. M. Danilenko, P. Valdez, I. Kasman, J. Eastham-Anderson, J. Wu, and W. Ouyang. 2007. Interleukin-22, a T(H)17 cytokine, mediates IL-23-induced dermal inflammation and acanthosis. Nature 445 (7128):648-51. 


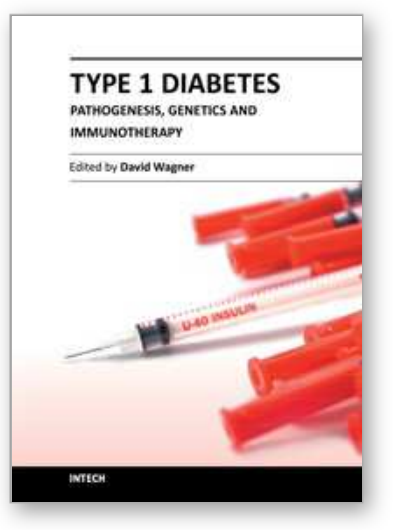

\author{
Type 1 Diabetes - Pathogenesis, Genetics and Immunotherapy \\ Edited by Prof. David Wagner
}

ISBN 978-953-307-362-0

Hard cover, 660 pages

Publisher InTech

Published online 25, November, 2011

Published in print edition November, 2011

This book is a compilation of reviews about the pathogenesis of Type 1 Diabetes. T1D is a classic autoimmune disease. Genetic factors are clearly determinant but cannot explain the rapid, even overwhelming expanse of this disease. Understanding etiology and pathogenesis of this disease is essential. A number of experts in the field have covered a range of topics for consideration that are applicable to researcher and clinician alike. This book provides apt descriptions of cutting edge technologies and applications in the ever going search for treatments and cure for diabetes. Areas including $T$ cell development, innate immune responses, imaging of pancreata, potential viral initiators, etc. are considered.

\title{
How to reference
}

In order to correctly reference this scholarly work, feel free to copy and paste the following:

William H.R. Langridge and Oludare J. Odumosu (2011). Multi-Component Vaccines for Suppression of Type 1 Diabetes, Type 1 Diabetes - Pathogenesis, Genetics and Immunotherapy, Prof. David Wagner (Ed.), ISBN: 978-953-307-362-0, InTech, Available from: http://www.intechopen.com/books/type-1-diabetes-pathogenesisgenetics-and-immunotherapy/multi-component-vaccines-for-suppression-of-type-1-diabetes

\section{INTECH}

open science | open minds

\section{InTech Europe}

University Campus STeP Ri

Slavka Krautzeka 83/A

51000 Rijeka, Croatia

Phone: +385 (51) 770447

Fax: +385 (51) 686166

www.intechopen.com

\section{InTech China}

Unit 405, Office Block, Hotel Equatorial Shanghai

No.65, Yan An Road (West), Shanghai, 200040, China

中国上海市延安西路65号上海国际贵都大饭店办公楼 405 单元

Phone: +86-21-62489820

Fax: $+86-21-62489821$ 
(C) 2011 The Author(s). Licensee IntechOpen. This is an open access article distributed under the terms of the Creative Commons Attribution 3.0 License, which permits unrestricted use, distribution, and reproduction in any medium, provided the original work is properly cited. 